\title{
SPRINTING. . . Dietary Approaches to Optimize Training Adaptation and Performance
}

\author{
Gary J. Slater \\ University of the Sunshine Coast \\ Jennifer Sygo \\ Athletics Canada \\ Majke Jorgensen \\ Team Danmark
}

\begin{abstract}
Although sprint athletes are assumed to primarily be interested in promoting muscle hypertrophy, it is the ability to generate explosive muscle power, optimization of power-to-weight ratio, and enhancement of anaerobic energy generation that are key outcomes of sprint training. This reflects the physique of track sprinters, being characterized as ecto-mesomorphs. Although there is little contemporary data on sprinters dietary habits, given their moderate energy requirements relative to body mass, a carbohydrate intake within the range of 3-6 $\mathrm{g} \cdot \mathrm{kg}^{-1} \cdot \mathrm{day}^{-1}$ appears reasonable, while ensuring carbohydrate availability is optimized around training. Similarly, although protein needs may be twice general population recommendations, sprint athletes should consume meals containing $\sim 0.4 \mathrm{~g} / \mathrm{kg}$ high biological value protein (i.e., easily digested, rich in essential amino acids) every 3-5 hr. Despite the short duration of competitions and relative long-recovery periods between races, nutrition still plays an important role in sprint performance. As energy expenditure moderates during competition, so too should intake of energy and macronutrients to prevent unwanted weight gain. Further adjustments in macronutrient intake may be warranted among athletes contemplating optimization of power-to-weight ratio through reductions in body fat prior to the competitive season. Other novel acute methods of weight loss have also been proposed to enhance power-to-weight ratio, but their implementation should only be considered under professional guidance. Given the metabolic demands of sprinting, a few supplements may be of benefit to athletes in training and/or competition. Their use in competition should be preceded with trialing in training to confirm tolerance and perceived ergogenic potential.
\end{abstract}

Keywords: athletics, nutrition, power-to-weight, anaerobic metabolism

Sprint performance, or the ability to generate maximal velocities, is important to competitive success across a range of sports including athletics events and team sports. The latter are characterized by repeated high-intensity sprints. By contrast, the track sprinter is concerned only with generating maximum velocity and with limiting the loss of this as the sprint progresses. The sprints contested at the summer Olympic Games and International Amateur Athletics Federation sanctioned events include the 100-, 200-, and 400-m sprints, $4 \times 100-, 4 \times 400-\mathrm{m}$ relay (male, female, and mixed gender), and the 100 (female)-/110 (male)- and 400-m hurdles.

This article is intended to serve as an update from the previous International Amateur Athletics Federation consensus on the role of nutrition in elite sprint performance (Tipton et al., 2007). When possible, emphasis is placed on research published since the previous consensus, and reference is made to other articles published in this series to reduce redundancy.

Slater is with the School of Health and Sport Sciences, University of the Sunshine Coast, Sippy Downs, Queensland, Australia. Sygo is with Athletics Canada, Ottawa, Ontario, Canada. Jorgensen is with Danish Elite Sport Institution, Team Danmark, Copenhagen, Denmark. Slater (gslater@usc.edu.au) is corresponding author.

\section{Determinants of Sprint Performance}

Sprint performance is determined primarily by reaction time, acceleration, maximum running velocity, and the ability to sustain this in the presence of increasing fatigue (Ross et al., 2001). A sprint event can be broken down into five interlinked components, including the reaction-response, block clearance, running acceleration, maximum velocity, and decreasing velocity, with the acceleration component contributing approximately two thirds of a race (Watts et al., 2012). During the longer 400-m sprint, running acceleration peaks during the first $100-150 \mathrm{~m}$, followed by a significantly longer decreasing velocity that is accentuated toward the finish of the race (Saraslanidis et al., 2011).

Having an appreciation of training and competition demands offers insight into optimum nutrition support for sprinters. Elite sprinters typically train for 1.5-4 hr/day, 5-6 days/week, with one or two of these days focused on low-intensity regenerative work. Training is typically periodized to develop maximum power of the major muscle groups using a range of modalities including sprinting but also plyometric exercises, resisted running drills, proprioceptive training, plus core stability, power, and Olympic lifts. This reflects the fact that maximal running speed is limited not by the capacity to move limbs quickly but rather by the capacity to 
produce the greatest ground force with the shortest ground contact time (Weyand et al., 2010). Sprint-specific training typically involves brief maximum intensity repetitions of varying length (both below and above competition distance), with either long- or shortrecovery periods. This style of training enhances traits important to athletic development and is common among explosive athletics disciplines.

The structure of the training day may include sprint/track training followed by resistance training, plus ancillary activities such as massage or soft-tissue treatment, travel time to and from the training facility, as well as academic, professional, or personal commitments. This schedule can have an important impact on meal timing and access to food to support pretraining fuelling and recovery and should be considered when developing a sprinter's nutrition plan.

Sprint-training adaptations can be separated into several distinct outcomes, including neural and metabolic (Dawson et al., 1998), as well as physique changes (Watts et al., 2012). Although adaptations are dependent on the specific training intervention applied, sprint training appears to induce favorable enzymatic adaptations across all three energy systems, resulting in faster rates of phosphocreatine breakdown and greater glycolytic and mitochondrial enzyme activity (Ross \& Leveritt, 2001).

Intense sprint exercise results in rapid increases in energy turnover from both aerobic and anaerobic metabolism. Having an appreciation of energy system contribution influences training prescription and directing nutrition guidelines for both training and competition. The relative energy system contribution varies between events, with the anaerobic energy system dominant across all distances. Anaerobic glycolysis is a dominant energy system, as is reflected in the high-lactate production, especially during the $400 \mathrm{~m}$ (Duffield et al., 2005). This ability to rapidly supply adenosine triphosphate through anaerobic sources correlates with performance in the sprint events. The relative aerobic contribution becomes more important as the distance increases (Table 1), with approximately $40 \%$ of energy derived from the aerobic metabolism in the $400 \mathrm{~m}$ in national caliber males and slightly higher in female athletes in season, although aerobic metabolism dominates after approximately 30 s (Spencer \& Gastin, 2001).

The ability to generate explosive muscle power and strength is critical to success in sprint events (Cunningham et al., 2013). Given the desire to enhance power-generating capacity, it is often assumed sprint athletes are primarily interested in promoting muscle hypertrophy. Although athletes may periodically attempt to promote skeletal muscle hypertrophy, key nutritional issues are broader than those pertinent to hypertrophy alone. These include the strategic timing of nutrient intake to maximize fuelling and recovery objectives, plus the enhancement of power-to-weight ratio, achieved through skeletal muscle hypertrophy and/or maintaining low body fat levels (Huovinen et al., 2015).

The source of fatigue during sprint training is likely multifactorial (Green, 1997), including neuromuscular and peripheral metabolic factors such as a decline in intramuscular $\mathrm{pH}$. The latter is somewhat dependent on the intensity and volume of training undertaken and the time point within a training session. Metabolic fatigue during the earlier part of a workout may be due in part to reductions in phosphagen energy system stores and mild acidosis, while subsequent fatigue may result more from acidosis and impaired energy production from glycogenolysis (Green, 1997). Interestingly, although multiple repeat sprints can have a significant impact on glycogen stores, data from cyclists suggests that low glycogen does not seem to impair single sprint performance (Hargreaves et al., 1997). Taken together, this provides potential opportunities for nutritional interventions that could impact on training and performance, including buffering against acidosis for longer sprints (i.e., $400 \mathrm{~m}$ ) and optimization of the phosphagen energy systems for shorter sprints (i.e., 100-, 200-m races).

\section{Physique and Body Composition Periodization}

Despite a long history of sprinting in the Olympic Games, relatively few studies describe the physique of elite sprinters. What is known is that successful sprinters have unique physical traits that predispose them to excellence. Some of these are responsive to training stimuli and/or nutritional interventions, including skeletal muscle fiber type and area (Dowson et al., 1998), fascicle area and length (Abe et al., 2001) plus adiposity (Dowson et al., 1998). However, other architectural features such as stature, toe, foot, and lower leg length are not responsive in the same way (Lee \& Piazza, 2009). The available literature clearly reflects an emphasis on the importance for sprinters to maximize skeletal muscle mass to enhance power. However, this may not be appropriate for all sprinters with skeletal muscle hypertrophy possibly resulting in adverse adaptations, including a transition away from fast-twitch glycolytic fibers and slower contraction velocity characteristics (Alway et al., 1988) if inappropriately prescribed. Thus, unless the increase in power proportionally exceeds any associated weight gain, sprint performance is unlikely to be enhanced by an increase in skeletal muscle mass.

Sprinters do tend to be heavier and more muscular than other runners. Early data from athletes participating in the 1960, 1968, and 1976 Olympic Games reported elite sprinters had a somatotype of 1.5-5-3 for males and 2.5-4-3 for females, with both genders characterized as ecto-mesomorphs (Carter, 1984). These ratings are consistent with more contemporary data (Abe et al., 2001) demonstrating that sprinters have higher muscularity and low relative adiposity. Sprinters are not on average the tallest or most ectomorphic of the running disciplines and are reported (Uth, 2005) to have a reasonably wide range for stature (men: $1.68-1.91 \mathrm{~m}$; women: $1.52-1.82 \mathrm{~m}$ ). However, in the past decade, the stature of successful male sprinters has been biased toward the upper limit or even exceeding this range, with speed records suggested to continue to be dominated by heavier and taller athletes (Charles \& Bejan, 2009).

A comprehensive description of the evolution of successful world-class $100-\mathrm{m}$ sprinter mass and stature characteristics is

Table 1 Relative Contribution of Aerobic and Anaerobic Metabolism to Sprint Performance (Duffield et al., 2005)

\begin{tabular}{lcccc}
\hline Event, $\mathbf{m}$ & \%Aerobic (male) & \%Anaerobic (male) & \%Aerobic (female) & \%Anaerobic (female) \\
\hline 100 & $20.4 \pm 7.9$ & $79.6 \pm 7.9$ & $25.0 \pm 7.4$ & $75.0 \pm 7.4$ \\
200 & $28.4 \pm 7.9$ & $71.6 \pm 7.9$ & $33.2 \pm 8.0$ & $66.8 \pm 8.0$ \\
400 & $41.3 \pm 10.9$ & $58.7 \pm 10.9$ & $44.5 \pm 7.6$ & $55.5 \pm 7.6$ \\
\hline
\end{tabular}

Note. Data are presented as $M \pm S D$. 
Table 2 Body Size and Shape Characteristics of Female World-Class Sprinters Per Decade

\begin{tabular}{lcccccc}
\hline Decade & $\boldsymbol{n}$ & Age (years) & Body mass $\mathbf{( k g )}$ & Stature $(\mathbf{m})$ & $\mathbf{B M I}\left(\mathbf{k g} / \mathbf{m}^{\mathbf{2}}\right)$ & $\mathbf{R P I}\left(\mathbf{c m} / \mathbf{k g} \mathbf{0 . 3 3 3}^{\mathbf{n}}\right.$ \\
\hline $1940-1949$ & 3 & $28.8 \pm 5.0$ & $65.3 \pm 9.9$ & $1.73 \pm 0.1$ & $21.7 \pm 1.4$ \\
$1950-1959$ & 2 & $28.5 \pm 6.4$ & $65.4 \pm 2.1$ & $1.74 \pm 0.02$ & $21.4 \pm 1.2$ \\
$1960-1969$ & 2 & $25.8 \pm 4.6$ & $58.5 \pm 2.1$ & $1.75 \pm 0.08$ & $19.4 \pm 1.2$ \\
$1970-1979$ & 2 & $23.4 \pm 4.1$ & $62.0 \pm 1.4$ & $1.73 \pm 0.04$ & $20.7 \pm 0.5$ & $20.4 \pm 1.1$ \\
$1980-1989$ & 71 & $25.0 \pm 3.1$ & $57.7 \pm 3.9$ & $1.68 \pm 0.05$ & $20.8 \pm 1.5$ \\
$1990-1999$ & 74 & $26.4 \pm 4.0$ & $59.1 \pm 5.2$ & $1.69 \pm 0.07$ & $43.1 \pm 1.6$ \\
$2000-2009$ & 74 & $26.2 \pm 3.9$ & $58.7 \pm 6.6$ & $1.66 \pm 0.07$ & $21.1 \pm 1.4$ \\
\hline
\end{tabular}

Note. Data are reported as $M \pm S D$. BMI = body mass index; RPI = reciprocal ponderal index. Adapted from "The Changing Shape Characteristics Associated With Success in World-Class Sprinters," by A. S. Watts, I. Coleman, and A. Nevill, 2012, Journal of Sports Sciences, 30(11), pp. 1085-1095.

Table 3 Body Size and Shape Characteristics of Male World-Class Sprinters Per Decade

\begin{tabular}{|c|c|c|c|c|c|c|}
\hline Decade & $n$ & Age (years) & Body mass $(\mathrm{kg})$ & Stature (m) & BMI $\left(\mathrm{kg} / \mathrm{m}^{2}\right)$ & $\mathrm{RPI}\left(\mathrm{cm} / \mathrm{kg}^{0.333}\right)$ \\
\hline $1910-19$ & 9 & $23.3 \pm 3.0$ & $69.2 \pm 3.6$ & $1.77 \pm 0.04$ & $22.1 \pm 1.4$ & $43.3 \pm 1.1$ \\
\hline $1920-29$ & 23 & $23.6 \pm 2.9$ & $69.5 \pm 4.7$ & $1.73 \pm 0.04$ & $23.3 \pm 1.3$ & $42.1 \pm 0.9$ \\
\hline $1930-39$ & 25 & $23.7 \pm 2.8$ & $74.6 \pm 6.7$ & $1.78 \pm 0.03$ & $23.4 \pm 1.8$ & $42.4 \pm 1.1$ \\
\hline $1940-49$ & 22 & $23.4 \pm 3.3$ & $72.4 \pm 4.6$ & $1.80 \pm 0.03$ & $22.5 \pm 1.8$ & $43.2 \pm 1.3$ \\
\hline $1950-59$ & 30 & $24.1 \pm 3.2$ & $71.9 \pm 6.3$ & $1.76 \pm 0.09$ & $23.3 \pm 2.3$ & $42.3 \pm 2.0$ \\
\hline $1960-69$ & 23 & $23.6 \pm 3.0$ & $75.9 \pm 7.3$ & $1.79 \pm 0.07$ & $23.7 \pm 1.3$ & $42.4 \pm 1.1$ \\
\hline $1970-79$ & 21 & $23.2 \pm 2.9$ & $76.9 \pm 5.4$ & $1.84 \pm 0.07$ & $22.8 \pm 1.9$ & $43.3 \pm 1.5$ \\
\hline $1980-89$ & 34 & $23.8 \pm 2.7$ & $73.7 \pm 6.0$ & $1.83 \pm 0.05$ & $21.9 \pm 1.2$ & $43.9 \pm 0.8$ \\
\hline 1990-99 & 54 & $26.1 \pm 3.5$ & $75.2 \pm 5.3$ & $1.80 \pm 0.05$ & $23.1 \pm 1.6$ & $42.8 \pm 1.2$ \\
\hline $2000-09$ & 99 & $25.6 \pm 3.4$ & $77.9 \pm 5.6$ & $1.81 \pm 0.06$ & $23.8 \pm 1.8$ & $42.5 \pm 1.4$ \\
\hline
\end{tabular}

Note. Data are reported as $M \pm S D$. BMI = body mass index; RPI = reciprocal ponderal index. Adapted from "The Changing Shape Characteristics Associated With Success in World-Class Sprinters," by A. S. Watts, I. Coleman, and A. Nevill, 2012, Journal of Sports Sciences, 30(11), pp. 1085-1095.

presented in Tables 2 and 3 (Watts et al., 2012). The available data span 10 decades (1910-2009) for men and eight (1940-2009) for women, although earlier female data are derived from case reports and, thus, include very small samples. Records typically included top 10, 100-m sprinters for both sexes during these periods. Athlete speed $(\mathrm{m} / \mathrm{s})$, body mass index (BMI, $\mathrm{kg} / \mathrm{m})$, and reciprocal ponderal index (RPI, $\mathrm{cm} / \mathrm{kg}^{0.333}$ ) were calculated. The BMI provided a proxy for muscularity, and the RPI provided a measure of linearity, with higher BMI and RPI representing greater muscularity and tallness/linearity, respectively. As expected, speed increased over the decades in both genders. Among male world-class sprinters, a high BMI was positively associated with success until the most recent decade where the trend was reversed. Most interesting was the finding that recently successful sprinters tended to have higher RPI. This was consistently observed over the decades for women with RPI positively associated with success and BMI exhibiting a weaker, negative association for speed. Taken together, it appears the influence of muscle mass on sprint performance is less important, with taller, more linear sprinters achieving greater success. This might be explained by the influence of stride length on sprint speed (Watts et al., 2012).

Interestingly, the current 100-m world record for women of 10.49 s attained in 1988 was for a runner (stature: $1.70 \mathrm{~m}$; mass: $59 \mathrm{~kg}$ ) with a more extreme RPI $\left(43.73 \mathrm{~cm} / \mathrm{kg}^{0.333}\right)$. The next closest time $(10.65 \mathrm{~s})$ to this long-standing world record was for another "linear" sprinter with an identical RPI (stature: $1.80 \mathrm{~m}$; mass: $70 \mathrm{~kg}$ ). In the men, the current world-record time (set in 2009) for 100-m sprint (9.58 s) was for an athlete with a stature of
$1.93 \mathrm{~m}$. It is recognized, however, that the use of prohibited performance-enhancing pharmaceuticals by some athletes may confound this type of analysis.

As elite sprinters are concerned with optimizing power-toweight ratio, there may be occasions when sprint athletes choose to restrict energy intake in the hope of reducing total body mass or fat mass, especially in advance of key races. When this is undertaken strategically to ensure retention of lean body mass and hormonal status, weight loss of as little as $2-3 \mathrm{~kg}$ can have a favorable impact on explosive power and speed (Huovinen et al., 2015). Despite the potential benefits of reducing body mass, sprint athletes may present with indicators of low energy availability, suggesting that attempts to restrict energy intake should be conducted with appropriate caution to ensure athlete health and performance are not compromised (Sygo et al., 2018).

Novel approaches to facilitate acute weight loss in an attempt to optimize power-to-weight ratio have anecdotally been implemented by some sprint athletes in recent times. Although there is no research supporting this practice in a sporting context, low-residue diets have been shown to facilitate weight loss within the range of 300-700 g (Rankin \& Gibson, 2015) and, thus, may be insufficient to significantly affect power-to-weight ratio in isolation. Intentional dehydration is an alternative approach to acutely promote sufficient weight loss to potentially favorably influence power-to-weight ratio. Indeed, there is some evidence to show an enhancement in vertical jump performance following dehydration equivalent to $\sim 3 \%$ of body mass (Viitasalo et al., 1987). Conversely, sprint performance over distances of 50-400 m remain stable despite an 
acute reduction in body mass equivalent to $2.0-2.5 \%$ facilitated through diuretic-induced dehydration (Watson et al., 2005). Athletes wishing to trial these acute weight loss strategies before competition should seek the advice of a university-qualified nutrition professional in advance so that health and performance implications can be more closely assessed.

Rather than absolute power output, acceleration in sprinting is also a function of power-to-weight ratio. Greater muscle strength and power are usually accompanied by an increase in muscle crosssectional area but the ability to generate force also requires improved neuromuscular recruitment. In a study comparing heavier, more muscular adults to adolescent sprinters, higher muscularity and mass were reported to explain slower sprint start dynamics in the adults (Aerenhouts et al., 2012). Although optimizing muscle mass is important for the development of explosive power, especially at the sprint start, training should advance technical skills to facilitate effective transfer of strength benefits. Although most studies report a "normalized' muscle strength of participants by adjusting for total or lean body mass, this unfortunately fails to adequately account for regional mass differences (e.g., differences in upper to lower body mass), which are likely to be important to performance. Locating mass closer to the joint center helps optimize biomechanical efficiency, a concept supported by research showing that sprinters with greater deposition of muscle in the upper portion of the quadriceps are faster (Handsfield et al., 2017).

Muscularity for sprinters needs to be optimized rather than maximized, and currently, there are insufficient comprehensive morphological data to provide detailed guidance. Small differences in adiposity on the limbs of sprinters have also been demonstrated to predict performance with relatively small reductions in medial calf skinfold associated with faster run times, at least in less elite runners (Legaz \& Eston, 2005). This suggests that subtle differences in the distribution of mass influences performance, possibly the result of increased muscular effort and energy expenditure associated with heavier lower limbs when running. This raises the concept of optimizing nutritional support of some training sessions to facilitate adaptation but not others. For example, support training sessions where hypertrophy may be beneficial, but do not optimize nutritional support of other sessions, where you want neural adaptations but not a hypertrophy response. Such an approach would demand strategic prescription of nutrition support in accordance with the training program, with significant dialog between athlete, coaching personnel, and university-qualified nutrition professional.

\section{Dietary Practices and Recommendations}

The dietary intakes of sprint athletes are poorly represented in the literature (Table 4) (Tipton et al., 2007) and may not accurately represent current practice, given the validity of methods used (Capling et al., 2017). When contrasted against other track-andfield athletes, relative energy and macronutrient intake are lower among sprinters than in the intake of middle-distance and longdistance runners (Sugiura et al., 1999). Despite this, micronutrient intakes are similar between runners. Less is known about the distribution of dietary intake throughout the day, including intake before, during, and after exercise, a time where nutrient intake can have a significant impact on not only substrate availability but also on adaptation to the training stimulus. Nutrition strategies to amplify training-induced adaptive signals outside of protein metabolism among sprint athletes remain to be explored.

\section{Carbohydrate}

The ergogenic potential of carbohydrate availability for sprint athletes is poorly understood. There is evidence that maintenance of an extremely low-carbohydrate diet can impair performance in events as brief as one 30-s sprint, presumably because of low muscle glycogen stores and decreased rates of glycolysis (Langfort et al., 1997). Indeed, muscle glycogen stores can be reduced by almost half following just three 30 -s maximal sprints. However, this alone does not appear to affect sprint exercise performance. Rather, fatigue may be caused by reduced creatine phosphate availability, increased hydrogen ion concentration, impairment in sarcoplasmic reticulum function, or some other fatigue-inducing agent (Hargreaves et al., 1998).

Within the training context, where multiple daily sessions are undertaken including repeat sprints and other modalities such as resistance training and plyometrics, carbohydrate availability may play a more important role, with muscle glycogen stores reduced by

\section{Table 4 Reported Daily Dietary Intake of Energy and Macronutrients Among Sprint Athletes During Training} (Unless Otherwise Stated) Since 1980

\begin{tabular}{|c|c|c|c|c|c|c|c|c|c|c|c|c|}
\hline \multirow[b]{2}{*}{ Gender } & \multirow[b]{2}{*}{ Population } & \multirow{2}{*}{$\begin{array}{c}\text { Body } \\
\text { mass (kg) }\end{array}$} & \multicolumn{2}{|c|}{ Energy } & \multicolumn{2}{|c|}{ Carbohydrate } & \multicolumn{2}{|c|}{ Protein } & \multicolumn{2}{|c|}{ Fat } & \multirow{2}{*}{$\begin{array}{l}\text { Survey } \\
\text { method }\end{array}$} & \multirow[b]{2}{*}{ References } \\
\hline & & & MJ & $\overline{k J / k g}$ & g & $\mathbf{g} / \mathbf{k g}$ & g & $\mathbf{g} / \mathbf{k g}$ & g & $\% \mathrm{E}$ & & \\
\hline \multirow[t]{4}{*}{ Male } & $\begin{array}{l}22.4 \pm 2.6 \text { years } \\
\text { National level } \\
(n=10)\end{array}$ & 67 & $11.1 \pm 1.5$ & $167 \pm 33$ & $340 \pm 57$ & $5.1 \pm 1.0$ & $102 \pm 20$ & $1.5 \pm 0.4$ & $90 \pm 16$ & $30 \pm 3$ & $\begin{array}{l}\text { 3-Day } \\
\text { diary }\end{array}$ & $\begin{array}{l}\text { Sugiura } \\
\text { et al. (1999) }\end{array}$ \\
\hline & $\begin{array}{l}\text { 12-18 years } \\
\text { Adolescent }(n=30)\end{array}$ & 61 & $11.1 \pm 1.5$ & 182 & $362 \pm 54$ & $6.0 \pm 0.9$ & $92 \pm 17$ & $1.5 \pm 0.3$ & $91 \pm 21$ & $30 \pm 5$ & $\begin{array}{l}\text { 7-Day } \\
\text { diary }\end{array}$ & $\begin{array}{l}\text { Aerenhouts } \\
\text { et al. (2008) }\end{array}$ \\
\hline & $\begin{array}{l}\text { National level } \\
(n=7)\end{array}$ & 74 & 8.5 & $154 \pm 33$ & 311 & $4.2 \pm 1.5$ & 155 & $2.1 \pm 0.5$ & 96 & 42 & $\begin{array}{l}\text { 4-Day } \\
\text { diary }\end{array}$ & $\begin{array}{l}\text { Huovinen } \\
\text { et al. (2015) }\end{array}$ \\
\hline & $\begin{array}{l}20-35 \text { years } \\
\text { National level } \\
(n=8)\end{array}$ & 80 & 11.9 & $149 \pm 23$ & 368 & $4.6 \pm 0.6$ & 168 & $2.1 \pm 0.7$ & 72 & 22 & $\begin{array}{l}\text { 4-Day } \\
\text { diary }\end{array}$ & $\begin{array}{l}\text { Huovinen } \\
\text { et al, (2015) }\end{array}$ \\
\hline \multirow[t]{2}{*}{ Female } & $\begin{array}{l}20.5 \pm 3.2 \text { years } \\
\text { National level } \\
(n=11)\end{array}$ & 54 & $10.0 \pm 2.2$ & $191 \pm 46$ & $305 \pm 79$ & $5.8 \pm 1.6$ & $89 \pm 25$ & $1.7 \pm 0.5$ & $86 \pm 17$ & $33 \pm 4$ & $\begin{array}{l}\text { 3-Day } \\
\text { diary }\end{array}$ & $\begin{array}{l}\text { Sugiura } \\
\text { et al. (1999) }\end{array}$ \\
\hline & $\begin{array}{l}12-18 \text { years } \\
\text { Adolescent }(n=26)\end{array}$ & 55 & $8.4 \pm 1.6$ & 153 & $273 \pm 54$ & $5.1 \pm 1.1$ & $78 \pm 15$ & $1.5 \pm 0.3$ & $69 \pm 17$ & $30 \pm 5$ & $\begin{array}{l}\text { 7-Day } \\
\text { diary }\end{array}$ & $\begin{array}{l}\text { Aerenhouts } \\
\text { et al. (2008) }\end{array}$ \\
\hline
\end{tabular}


70-80\% following repeated 60-s sprints (MacDougall et al., 1977). These reductions in substrate availability are probably sufficient to impair both repeat sprint performance (Rockwell et al., 2003) and other forms of training undertaken by sprinters. Furthermore, a single resistance-training session can reduce muscle glycogen stores by as much as $24-40 \%$ (Koopman et al., 2006). Reductions in muscle glycogen stores have been associated with performance impairment in both isokinetic torque and isoinertial resistancetraining capacity. Thus, it is plausible that impaired training performance could occur in any session that relies on rapid and repeated glycogen breakdown. If the low-carbohydrate status is achieved through a low-carbohydrate, high-protein diet, acid-base status may also be impaired if sustained, further adversely affecting performance (Maughan et al., 1997).

Athletes are encouraged to pay particular attention to dietary intake in the hours before exercise, under the assumption that preexercise nutritional strategies can influence exercise performance. Evidence is present for a beneficial role of acute carbohydrate ingestion before and/or during strength training (Lambert et al., 1991). However, not all investigations show a benefit of acute carbohydrate ingestion (Kulik et al., 2008). It is proposed that the ergogenic potential for carbohydrate ingestion is most likely to be observed when elite sprint athletes are undertaking longer duration, high-volume training. Currently, specific recommendations for an optimum rate or timing of carbohydrate ingestion for sprint athletes before and during any given training session cannot be made. Furthermore, any nonmetabolic response from mouth rinsing a carbohydrate solution does not appear to influence sprint performance (Painelli et al., 2011), although the impact on training capacity warrants further investigation, especially among athletes who experience gastrointestinal tract distress.

Dietary survey literature relating to sprint athletes suggests that they typically report daily carbohydrate intakes of 4-6 g/kg body mass, independent of gender (Table 4). Although this may appear low relative to the intakes of endurance athletes and may be amplified by underreporting common among dietary assessment methodology (Capling et al., 2017), there is no conclusive evidence of benefit from maintaining a high habitual carbohydrate intake among sprint athletes. Given the lower relative energy expenditure of larger athletes, their requirements for other nutrients, plus the effect of adjusting carbohydrate on total energy intake, recommendations for carbohydrate intake at strategic times, including before, during, and after exercise, may be more applicable for the sprint athlete. This would ensure carbohydrate availability is optimized at critical time points. Thus, a range of daily carbohydrate intakes between 3 and $6 \mathrm{~g} / \mathrm{kg}$ body mass strategically allocated across the day would be considered reasonable for sprint athletes depending on their phase of training (Bartlett et al., 2015).

\section{Protein}

Strength-power athletes such as sprinters have advocated highprotein diets for many years. Although debate continues on the need for additional protein among sprint-trained athletes, general guidelines now recommend that athletes undertaking strengthpower training ingest approximately twice the current recommendations for protein of their sedentary counterparts or as much as 1.6-2.2 $\mathrm{g} \cdot \mathrm{kg}^{-1} \cdot \mathrm{day}^{-1}$ (Stokes et al., 2018). Given the relatively wide distribution of protein in the meal plan and increased energy intake of athletes, it is not surprising to learn that the majority of sprint athletes achieve these increased protein intake targets (Table 4). Exceeding the upper range of protein intake guidelines likely offers no further benefit and simply promotes increased amino acid catabolism and protein oxidation (Witard et al., 2014). Furthermore, there is evidence that an intense period of resistance training reduces protein turnover and improves net protein retention (Phillips et al., 1999), thus reducing relative dietary protein requirements of experienced resistance-trained athletes.

Simply contrasting an athlete's current daily protein intake against generic guidelines does not address whether protein intake has been optimized to promote gains in muscle mass or repair damaged tissues. Rather, consideration should be given to other dietary factors, including total energy intake and the daily distribution and biological value of ingested protein. Although there is little information available on the eating patterns of sprint athletes, available literature on athletic populations suggests that the majority of daily protein intake is skewed toward the evening, with little consideration for breakfast or between-meal intake (Gillen et al., 2017). Thus, rather than focusing on total daily intake, sprint athletes are encouraged to consume meals containing $\sim 0.4 \mathrm{~g} / \mathrm{kg}$ high biological value protein every $3-5 \mathrm{hr}$ (Witard et al., 2018). Further investigation of contemporary dietary practices of sprint athletes using valid tools is clearly warranted.

\section{Hydration}

As with all athletes, sprint athletes are encouraged to initiate training in a euhydrated state. However, the duration of sprint events ensures that no hydration intervention is warranted during the event itself. Furthermore, the reduction in body mass associated with hypohydration may reduce the work required to accelerate the body, compensating for any reduction in muscular strength/power (Maughan \& Shirreffs, 2010). Despite this, longer duration activities undertaken by sprint athletes such as resistance training are impaired by hypohydration (Kraft et al., 2010). On the weight of this evidence, track-sprinting performance does not appear to be influenced by a state of hypohydration within the range of $2-3 \%$, especially among trained individuals (Savoie et al., 2015). However, sprint training characterized by repeat high-intensity efforts may be impaired by hypohydration. Sprint athletes are advised to start training in a state of euhydration, drink to their thirst and gastrointestinal tolerance, and limit body mass loss to no more than 2-3\% during any one training session, complementing this with aggressive postexercise recovery strategies, inclusive of adequate fluid and electrolytes. See also Casa et al. (2018).

\section{Recovery}

Given that sprint athletes typically undertake multiple daily training sessions, posttraining nutritional recovery strategies are advocated. The acute ingestion of carbohydrate and protein combined after sprint training results in more favorable recovery outcomes, including restoration of muscle glycogen stores and muscle protein metabolism, than the ingestion of either nutrient alone. Postexercise protein ingestion also lowers carbohydrate intake requirements in the acute recovery period, with an energy-matched intake of $0.8 \mathrm{~g} \cdot \mathrm{kg}^{-1} \cdot \mathrm{hr}^{-1}$ carbohydrate plus $0.4 \mathrm{~g} \cdot \mathrm{kg}^{-1} \cdot \mathrm{hr}^{-1}$ protein resulting in similar muscle glycogen resynthesis over $5 \mathrm{hr}$ compared with $1.2 \mathrm{~g} \cdot \mathrm{kg}^{-1} \cdot \mathrm{hr}^{-1}$ carbohydrate alone following intermittent exercise (van Loon et al., 2000), with a similar response evident following resistance exercise. Preliminary evidence also suggests the postexercise coingestion of carbohydrate and protein may reduce the muscle damage often seen in strength-trained athletes (Cockburn et al., 2010); whether such a response has a functional benefit is unclear. 
Another potential strategy to attenuate the exercise-induced muscle damage common among sprint athletes involves the ingestion of phytonutrient-rich foods such as blueberries, pomegranate, and tart cherry (Levers et al., 2015). The integration of these whole foods or their concentrates into the meal plan of sprint athletes holds interesting promise and warrants further investigation, at least when the focus is on recovery, rather than adaptation (Vitale et al., 2017).

\section{Supplementation}

Supplement use among runners varies based on the event, with sprinters reported to have both higher (Tscholl et al., 2010) and lower (Maughan et al., 2007) rates of supplement use relative to distance runners, with polysupplementation common. Although multivitamin and mineral supplements remain popular, protein powders and specific amino acid supplements, caffeine, and creatine monohydrate are also frequently used by sprinters (Tscholl et al., 2010). Similar to other track-and-field athletes, sprinters are motivated to take supplements to enhance recovery, health, and performance (Peeling et al., 2019).

The majority of the energy required during a single bout of brief, maximal exercise is provided through anaerobic pathways, specifically glycogenolysis resulting in phosphocreatine degradation and lactate formation (Duffield et al., 2005). Interventions able to influence energy availability through these pathways may favorably affect sprint exercise performance. After reviewing the metabolic demands of sprinting, several supplements might benefit the sprint athlete, whether in training or competition, and these are summarized in Table 5 and discussed in detail elsewhere (Peeling et al., 2019).

Creatine monohydrate supplementation has the potential to favorably impact on sprint performance, given the ability to aid in the rapid rephosphorylation of high-energy phosphates and

\section{Table 5 Ergogenic Aids of Potential Benefit for Sprinters and Sprint Hurdlers}

\begin{tabular}{|c|c|c|c|c|c|}
\hline $\begin{array}{l}\text { Supplement } \\
\text { name }\end{array}$ & Details $^{a}$ & Event(s) & Training & Competition & References \\
\hline $\begin{array}{l}\text { Creatine } \\
\text { monohydrate }\end{array}$ & $\begin{array}{l}\text { Aids in rapid rephosphory- } \\
\text { lation of high-energy phos- } \\
\text { phates and shortens muscle } \\
\text { relaxation time } \\
\text { May improve both } \\
\text { individual and repeat } \\
\text { sprint performances } \\
\text { Increases work capacity, } \\
\text { potentially augmenting } \\
\text { training adaptations for both } \\
\text { sprint and ancillary training } \\
\text { (weight room, plyometrics) }\end{array}$ & $\begin{array}{l}\text { All sprints but poten- } \\
\text { tially greatest benefit } \\
\text { for shorter sprints } \\
(100 \mathrm{~m}, 200 \mathrm{~m})\end{array}$ & $\begin{array}{l}\text { Yes; can provide benefit } \\
\text { for both maximal and } \\
\text { repeat sprint efforts and } \\
\text { weight room activities }\end{array}$ & $\begin{array}{l}\text { Possibly; sprinters must } \\
\text { weigh potential perfor- } \\
\text { mance benefits vs. } \\
\text { energetic costs associ- } \\
\text { ated with extra body } \\
\text { mass and fluid retention } \\
\text { that may occur with } \\
\text { creatine monohydrate } \\
\text { supplementation }\end{array}$ & $\begin{array}{l}\text { Bemben and Lamont } \\
\text { (2005), Haff et al. } \\
\text { (2000), and Skare } \\
\text { et al. (2001) }\end{array}$ \\
\hline $\begin{array}{l}\text { Sodium } \\
\text { bicarbonate }\end{array}$ & $\begin{array}{l}\text { Acts as a buffer against } \\
\text { acid-base disturbances, } \\
\text { providing performance } \\
\text { enhancement during sprints } \\
\text { of } \sim 60 \text {-s duration }\end{array}$ & $\begin{array}{l}400 \mathrm{~m}, 400 \text {-m hurdles; } \\
\text { impact on shorter } \\
\text { sprints unknown but } \\
\text { is likely smaller than } \\
\text { observed in longer } \\
\text { sprints }\end{array}$ & $\begin{array}{l}\text { Yes; may provide addi- } \\
\text { tional buffering capacity } \\
\text { for repeat sprints }\end{array}$ & $\begin{array}{l}\text { Possibly; consideration } \\
\text { must be given to } \\
\text { potentially undesirable } \\
\text { gastrointestinal side ef- } \\
\text { fects and acute body } \\
\text { mass gains through } \\
\text { fluid retention }\end{array}$ & $\begin{array}{l}\text { Carr et al. (2011), } \\
\text { Edge et al. (2006), } \\
\text { and Zabala et al. } \\
\text { (2011) }\end{array}$ \\
\hline$\beta$-Alanine & $\begin{array}{l}\text { Acts as a physiochemical } \\
\text { buffer by increasing } \\
\text { muscle carnosine } \\
\text { Muscle carnosine concen- } \\
\text { tration is correlated with } \\
\text { increased power output } \\
\text { during 30-s sprints, } \\
\text { especially in latter half } \\
\text { of the sprint }\end{array}$ & $400 \mathrm{~m}, 400-\mathrm{m}$ hurdles & $\begin{array}{l}\text { Yes; greatest benefit in } \\
\text { events } \sim 1-10 \text { min long, } \\
\text { suggesting greatest bene- } \\
\text { fits may be observed in } \\
\text { training vs. competition in } \\
\text { sprint athletes }\end{array}$ & $\begin{array}{l}\text { Yes, although benefits } \\
\text { in highly trained sprin- } \\
\text { ters are likely to be } \\
\text { lower }\end{array}$ & $\begin{array}{l}\text { Blancquaert et al. } \\
\text { (2015), Hobson et al. } \\
\text { (2013), Saunders } \\
\text { et al. (2017), and } \\
\text { Suzuki et al. (2002) }\end{array}$ \\
\hline Dietary nitrate & $\begin{array}{l}\text { Improved muscle } \\
\text { oxygenation } \\
\text { Improved muscle } \\
\text { metabolic efficiency } \\
\text { Improved contractile } \\
\text { function }\end{array}$ & $\begin{array}{l}400 \mathrm{~m}, 400-\mathrm{m} \text { hurdles; } \\
\text { possibly } 100 \mathrm{~m} \text { and } \\
200 \mathrm{~m} \text { and shorter } \\
\text { hurdles }\end{array}$ & $\begin{array}{l}\text { Possibly; maximal and } \\
\text { intermittent sprint } \\
\text { performance enhanced } \\
\text { in sprint-interval-trained } \\
\text { athletes }\end{array}$ & $\begin{array}{l}\text { Possibly; performance } \\
\text { benefit may be greatest } \\
\text { in longer sprints } \\
(400 \mathrm{~m}, 400 \text {-m hurdles })\end{array}$ & $\begin{array}{l}\text { Jones (2014) and } \\
\text { Thompson et al. } \\
(2016)\end{array}$ \\
\hline Caffeine & $\begin{array}{l}\text { Adenosine antagonist, } \\
\text { reducing fatigue and } \\
\text { increasing alertness and } \\
\text { motivation }\end{array}$ & All & $\begin{array}{l}\text { Possibly; impact on sprint } \\
\text { performance is not well } \\
\text { described and can be con- } \\
\text { tradictory; consideration } \\
\text { must be given to tolerance, } \\
\text { excessive alertness, and } \\
\text { heart palpitations }\end{array}$ & $\begin{array}{l}\text { Possibly; some evi- } \\
\text { dence suggest that } \\
5 \mathrm{mg} / \mathrm{kg} \text { body mass can } \\
\text { enhance both single } \\
\text { and multiple sprint } \\
\text { performance }\end{array}$ & $\begin{array}{l}\text { Astorino and } \\
\text { Roberson (2010) and } \\
\text { Glaister et al. (2008) }\end{array}$ \\
\hline
\end{tabular}

${ }^{a}$ For supplement dosing protocols, including acute pretraining and competition dosing, and loading/chronic usage protocols, see Peeling et al. (2019). 
enhance buffering capacity (Bemben \& Lamont, 2005). Given the dependence on anaerobic glycogenolysis and associated acid-base disturbances, sprint performance may be enhanced if buffering capacity can be increased through the ingestion of acute buffering agents such as sodium bicarbonate. This may be especially relevant for the longer duration $(400 \mathrm{~m})$ sprints characterized by substantial acid-base disturbances. More recently, there has been significant interest in the histidine-containing dipeptide carnosine, which contributes significantly to the physiochemical buffering in skeletal muscles. The manipulation of both blood (sodium bicarbonate or sodium citrate supplementation) and muscle-buffering capacity ( $\beta$-alanine supplementation) in combination (Hobson et al., 2013) or through dietary manipulation also has potential (Limmer et al., 2018).

Recent evidence suggests that dietary nitrate supplementation may have the potential to enhance sprint performance, possibly because of improved muscle oxygenation, muscle metabolic efficiency, and/or contractile function (Jones, 2014). Finally, caffeine ingestion can enhance both single- and multiple-sprint performance (Glaister et al., 2008), and its use should be considered in sprinttrained athletes, although the potential negative implications on subsequent sleep warrant consideration (Dunican et al., 2018).

\section{Competition Nutrition Strategies}

In major competitions, a sprint athlete must advance through qualifying rounds: a semifinal and final, each typically separated by several hours, and in the case of the longer sprints, typically a 24-hr period. Given the brief nature of sprint events, the relative importance of competition nutrition strategies might be assumed to be negligible. However, there is evidence to suggest that precompetition nutrition, including the use of some ergogenic aids, influences performance outcomes in these events.

Competition demands of sprinters are typically characterized by high-intensity efforts lasting approximately 10-60 s, with significant recovery between races. Due to the scheduling of major competitions, it is rare for elite sprinters to participate in more than two individual events, although athletes competing in multiple events, including relays, may have several races on a single day. With significant periods for recovery between races, muscle energy reserves are unlikely to be depleted, even in challenging environmental conditions of competitions such as the summer Olympic Games. Consequently, prerace nutrition priorities remain together with more general goals, for example, optimizing gastrointestinal tract comfort and preventing weight gain during the competition taper.

Major international track-and-field competitions generally see the initial heats of an event being held early in the day, while finals are often run in the evening. Prerace nutrition from qualifying rounds to finals may, therefore, involve different meals. A key consideration for the prerace meal, regardless of the time of day, is to consume a comfortable, familiar meal. The shorter duration of sprint events means that gastrointestinal disturbances are not as commonly reported but inappropriate food selection may affect an athlete's energy availability and gut comfort. A state of lowcarbohydrate availability has been shown to impair anaerobic work capacity (Langfort et al., 1997) and peak power output (Wroble et al., 2018). However, this effect is evident only following severe dietary carbohydrate restriction, sufficient to promote a state of ketosis. Such a state is unlikely among competitive athletes tapering prior to competition who follow a meal plan with even a moderate carbohydrate content. In light of this, sprint athletes are advised to choose a familiar meal ideally containing $1-2 \mathrm{~g} / \mathrm{kg}$ body mass of carbohydrate approximately $1-4 \mathrm{hr}$ prior to competition.

The use of prerace ergogenic aids, such as buffering agents or caffeine, requires careful consideration of the competition schedule. athletes who are using these products should determine the optimum dosage and timing for enhanced performance across single and repeat performances, as repeat dosing may be considered when races are close together, such as the 100-m semifinal and final. Administering a standard dose prior to each race may result in adverse outcomes depending on the specific product and its halflife. Given this, it is essential that athletes should trial supplement strategies in training or smaller competitions to determine optimal dosage and timing of administration. In the case of bicarbonate, this may result in an athlete choosing to complete a chronic supplementation strategy over a period of days, rather than an acute loading protocol immediately prior to competition (McNaughton \& Thompson, 2001).

Postrace recovery strategies should emphasize muscle repair, replenishment of carbohydrate stores, and adequate rehydration, while considering the multiple activities that can compete for a sprinter's time and attention after competition (e.g., cooldown, massage or treatment, doping control, media, time with friends and family, and travel from the competition venue). As such, sprinters competing in multiple events would be well-advised to bring recovery foods to the competition venue, emphasizing rapidly digested protein and carbohydrates, as well as antioxidant-rich foods and fluids such as tart cherry or pomegranate juice.

\section{Conclusions}

Nutrition plays a number of important roles for elite sprint athletes. Sprint athletes will benefit from a greater focus on training nutrition, given the metabolic demands of training far exceed those of competition. An emphasis should be placed on the strategic timing of nutrient intake before, during, and after exercise to assist sprinters in optimizing resistance-training work capacity, recovery, and body composition. Although it is often assumed that sprint athletes are primarily interested in promoting muscle hypertrophy, optimization of body composition demands consideration of the effect of any changes in physical traits on power-to-weight ratio and biomechanical efficiency. Nutritional supplements remain very popular among sprinters, and there is some evidence to support the use of a small number of products to assist elite sprinters, albeit marginally, in the training and/or competition environment. However, advice should first be sought from university-qualified, performance nutrition-focused professionals. Any proposed dietary interventions should be trialled in training to assess tolerance and likely individual performance response.

\section{Acknowledgments}

Manuscript preparation was undertaken by G. J. Slater, J. Sygo, and M. Jorgensen. All authors approved the final version of the article. No author had any conflict of interest.

\section{References}

Abe, T., Fukashiro, S., Harada, Y., \& Kawamoto, K. (2001). Relationship between sprint performance and muscle fascicle length in female sprinters. Journal of Physiological Anthropology and Applied Human Science, 20(2), 141-147. PubMed ID: 11385937 doi:10.2114/jpa. 20.141 
Aerenhouts, D., Delecluse, C., Hagman, F., Taeymans, J., Debaere, S., Van Gheluwe, B., \& Clarys, P. (2012). Comparison of anthropometric characteristics and sprint start performance between elite adolescent and adult sprint athletes. European Journal of Sport Science, 12(1), 9-15. doi:10.1080/17461391.2010.536580

Aerenhouts, D., Hebbelinck, M., Poortmans, J.R., \& Clarys, P. (2008). Nutritional habits of Flemish adolescent sprint athletes. International Journal of Sport Nutrition and Exercise Metabolism, 18(5), 509-523. PubMed ID: 19033612 doi:10.1123/ijsnem.18.5.509

Alway, S.E., MacDougall, J.D., Sale, D.G., Sutton, J.R., \& McComas, A.J. (1988). Functional and structural adaptations in skeletal muscle of trained athletes. Journal of Applied Physiology, 64(3), 1114-1120. PubMed ID: 3366734 doi:10.1152/jappl.1988.64.3.1114

Astorino, T.A., \& Roberson, D.W. (2010). Efficacy of acute caffeine ingestion for short-term high-intensity exercise performance: A systematic review. The Journal of Strength and Conditioning Research, 24(1), 257-265. PubMed ID: 19924012 doi:10.1519/ JSC.0b013e3181c1f88a

Bartlett, J.D., Hawley, J.A., \& Morton, J.P. (2015). Carbohydrate availability and exercise training adaptation: Too much of a good thing? European Journal of Sport Science, 15(1), 3-12. PubMed ID: 24942068 doi:10.1080/17461391.2014.920926

Bemben, M.G., \& Lamont, H.S. (2005). Creatine supplementation and exercise performance: Recent findings. Sports Medicine, 35(2), 107125. PubMed ID: 15707376 doi:10.2165/00007256-20053502000002

Blancquaert, L., Everaert, I., \& Derave, W. (2015). Beta-alanine supplementation, muscle carnosine and exercise performance. Current Opinion in Clinical Nutrition and Metabolic Care, 18(1), 63-70. PubMed ID: 25474013 doi:10.1097/MCO.0000000000000127

Capling, L., Beck, K.L., Gifford, J.A., Slater, G., Flood, V.M., \& O'Connor, H. (2017). Validity of Dietary Assessment in Athletes: A systematic review. Nutrients, 9(12), pii: E1313. doi:10.3390/ nu9121313

Carr, A.J., Hopkins, W.G., \& Gore, C.J. (2011). Effects of acute alkalosis and acidosis on performance: A meta-analysis. Sports Medicine, 41(10), 801-814. PubMed ID: 21923200 doi:10.2165/11591440000000000-00000

Carter, J. (1984). Somatotypes of Olympic athletes from 1948-1976. In J. Carter (Ed.), Physical structure of Olympic athletes. Part II: Kinanthropometry of Olympic athletes (pp. 80-109). Basel, Switzerland: Karger.

Casa, D.J., Cheuvront, S.N., Galloway, S.R., \& Shirreffs, S.M. (2019). Fluid needs for training, competition and recovery in track-and-field athletes. International Journal of Sport Nutrition and Exercise Metabolism, 29. doi:10.1123/ijsnem.2018-0374

Charles, J.D., \& Bejan, A. (2009). The evolution of speed, size and shape in modern athletics. Journal of Experimental Biology, 212(Pt 15), 2419-2425. PubMed ID: 19617435 doi:10.1242/jeb. 031161

Cockburn, E., Stevenson, E., Hayes, P.R., Robson-Ansley, P., \& Howatson, G. (2010). Effect of milk-based carbohydrate-protein supplement timing on the attenuation of exercise-induced muscle damage. Applied Physiology, Nutrition, and Metabolism, 35(3), 270-277. PubMed ID: 20555370 doi:10.1139/H10-017

Cunningham, D.J., West, D.J., Owen, N.J., Shearer, D.A., Finn, C.V., Bracken, R.M., ... Kilduff, L.P. (2013). Strength and power predictors of sprinting performance in professional rugby players. The Journal of Sports Medicine and Physical Fitness, 53(2), 105-111. PubMed ID: 23584316

Dawson, B., Fitzsimons, M., Green, S., Goodman, C., Carey, M., \& Cole, K. (1998). Changes in performance, muscle metabolites, enzymes and fibre types after short sprint training. European Journal of Applied Physiology and Occupational Physiology, 78(2), 163-169. PubMed ID: 9694316 doi:10.1007/s004210050402

Dowson, M.N., Nevill, M.E., Lakomy, H.K., Nevill, A.M., \& Hazeldine, R.J. (1998). Modelling the relationship between isokinetic muscle strength and sprint running performance. Journal of Sports Sciences, 16(3), 257-265. PubMed ID: 9596360 doi:10.1080/ 026404198366786

Duffield, R., Dawson, B., \& Goodman, C. (2005). Energy system contribution to 400-metre and 800-metre track running. Journal of Sports Sciences, 23(3), 299-307. PubMed ID: 15966348 doi:10.1080/ 02640410410001730043

Dunican, I.C., Higgins, C.C., Jones, M.J., Clarke, M.W., Murray, K., Dawson, B., ... Eastwood, P.R. (2018). Caffeine use in a Super Rugby game and its relationship to post-game sleep. European Journal of Sport Science, 18(4), 513-523.

Edge, J., Bishop, D., \& Goodman, C. (2006). Effects of chronic NaHCO3 ingestion during interval training on changes to muscle buffer capacity, metabolism, and short-term endurance performance. Journal of Applied Physiology, 101(3), 918-925. PubMed ID: 16627675 doi:10.1152/japplphysiol.01534.2005

Gillen, J.B., Trommelen, J., Wardenaar, F.C., Brinkmans, N.Y., Versteegen, J.J., Jonvik, K.L., . . van Loon, L.J. (2017). Dietary Protein Intake and Distribution Patterns of Well-Trained Dutch Athletes. International Journal of Sport Nutrition and Exercise Metabolism, 27(2), 105-114. PubMed ID: 27710150 doi:10.1123/ ijsnem.2016-0154

Glaister, M., Howatson, G., Abraham, C.S., Lockey, R.A., Goodwin, J.E., Foley, P., \& McInnes, G. (2008). Caffeine supplementation and multiple sprint running performance. Medicine \& Science in Sports \& Exercise, 40(10), 1835-1840. PubMed ID: 18799995 doi:10.1249/ MSS.0b013e31817a8ad2

Green, H.J. (1997). Mechanisms of muscle fatigue in intense exercise. Journal of Sports Sciences, 15(3), 247-256. PubMed ID: 9232550 doi:10.1080/026404197367254

Haff, G.G., Kirksey, K.B., Stone, M.H., Warren, B.J., Johnson, R.L., Stone, M., .. Proulx, C. (2000). The Effect of 6 Weeks of Creatine Monohydrate Supplementation on Dynamic Rate of Force Development. The Journal of Strength and Conditioning Research, 14(4), 426-433.

Handsfield, G.G., Knaus, K.R., Fiorentino, N.M., Meyer, C.H., Hart, J.M., \& Blemker, S.S. (2017). Adding muscle where you need it: Nonuniform hypertrophy patterns in elite sprinters. Scandinavian Journal of Medicine \& Science in Sports, 27(10), 1050-1060. PubMed ID: 27373796 doi:10.1111/sms.12723

Hargreaves, M., Finn, J.P., Withers, R.T., Halbert, J.A., Scroop, G.C., Mackay, M., ... Carey, M.F. (1997). Effect of muscle glycogen availability on maximal exercise performance. European Journal of Applied Physiology and Occupational Physiology, 75(2), 188-192. PubMed ID: 9118987 doi:10.1007/s004210050146

Hargreaves, M., McKenna, M.J., Jenkins, D.G., Warmington, S.A., Li, J.L., Snow, R.J., \& Febbraio, M.A. (1998). Muscle metabolites and performance during high-intensity, intermittent exercise. Journal of Applied Physiology, 84(5), 1687-1691. PubMed ID: 9572818 doi:10. 1152/jappl.1998.84.5.1687

Hobson, R.M., Harris, R.C., Martin, D., Smith, P., Macklin, B., Gualano, B., \& Sale, C. (2013). Effect of beta-alanine, with and without sodium bicarbonate, on 2000-m rowing performance. International Journal of Sport Nutrition and Exercise Metabolism, 23(5), 480-487. PubMed ID: 23535873 doi:10.1123/ijsnem.23.5.480

Huovinen, H.T., Hulmi, J.J., Isolehto, J., Kyrolainen, H., Puurtinen, R., Karila, T., ... Mero, A.A. (2015). Body composition and power 
performance improved after weight reduction in male athletes without hampering hormonal balance. The Journal of Strength and Conditioning Research, 29(1), 29-36. PubMed ID: 25028999 doi:10.1519/ JSC.0000000000000619

Jones, A.M. (2014). Dietary nitrate supplementation and exercise performance. Sports Medicine, 44(Suppl. 1), S35-S45. doi:10.1007/ s40279-014-0149-y

Koopman, R., Manders, R.J., Jonkers, R.A., Hul, G.B., Kuipers, H., \& van Loon, L.J. (2006). Intramyocellular lipid and glycogen content are reduced following resistance exercise in untrained healthy males. European Journal of Applied Physiology, 96(5), 525-534. PubMed ID: 16369816 doi:10.1007/s00421-005-0118-0

Kraft, J.A., Green, J.M., Bishop, P.A., Richardson, M.T., Neggers, Y.H., \& Leeper, J.D. (2010). Impact of dehydration on a full body resistance exercise protocol. European Journal of Applied Physiology, 109(2), 259-267. PubMed ID: 20066432 doi:10.1007/s00421-009-1348-3

Kulik, J.R., Touchberry, C.D., Kawamori, N., Blumert, P.A., Crum, A.J., \& Haff, G.G. (2008). Supplemental carbohydrate ingestion does not improve performance of high-intensity resistance exercise. The Journal of Strength and Conditioning Research, 22(4), 1101-1107. PubMed ID: 18545201 doi:10.1519/JSC.0b013e31816d679b

Lambert, C.P., Flynn, M.G., Boone, J.B.J., Michaud, T.J., \& RodriguezZayas, J. (1991). Effects of Carbohydrate Feeding on Multiple-bout Resistance Exercise. The Journal of Strength and Conditioning Research, 5(4), 192-197.

Langfort, J., Zarzeczny, R., Pilis, W., Nazar, K., \& Kaciuba-Uscitko, H. (1997). The effect of a low-carbohydrate diet on performance, hormonal and metabolic responses to a 30-s bout of supramaximal exercise. European Journal of Applied Physiology and Occupational Physiology, 76(2), 128-133. PubMed ID: 9272770 doi:10.1007/ s004210050224

Lee, S.S., \& Piazza, S.J. (2009). Built for speed: Musculoskeletal structure and sprinting ability. Journal of Experimental Biology, 212(Pt 22), 3700-3707. PubMed ID: 19880732 doi:10.1242/jeb.031096

Legaz, A., \& Eston, R. (2005). Changes in performance, skinfold thicknesses, and fat patterning after three years of intense athletic conditioning in high level runners. British Journal of Sports Medicine, 39(11), 851-856. PubMed ID: 16244197 doi:10.1136/bjsm.2005. 018960

Levers, K., Dalton, R., Galvan, E., Goodenough, C., O’Connor, A., Simbo, S., ... Kreider, R.B. (2015). Effects of powdered Montmorency tart cherry supplementation on an acute bout of intense lower body strength exercise in resistance trained males. Journal of the International Society of Sports Nutrition, 12, 41. PubMed ID: 26578852 doi:10.1186/s12970-015-0102-y

Limmer, M., Eibl, A.D., \& Platen, P. (2018). Enhanced 400-m sprint performance in moderately trained participants by a 4-day alkalizing diet: A counterbalanced, randomized controlled trial. Journal of the International Society of Sports Nutrition, 15(1), 25. PubMed ID: 29855319 doi:10.1186/s12970-018-0231-1

MacDougall, J.D., Ward, G.R., \& Sutton, J.R. (1977). Muscle glycogen repletion after high-intensity intermittent exercise. Journal of Applied Physiology, 42(2), 129-132. PubMed ID: 838636 doi:10.1152/jappl .1977 .42 .2 .129

Maughan, R.J., Depiesse, F., \& Geyer, H. (2007). The use of dietary supplements by athletes. Journal of Sports Sciences, 25(Suppl. 1), S103-S113. doi:10.1080/02640410701607395

Maughan, R.J., Greenhaff, P.L., Leiper, J.B., Ball, D., Lambert, C.P., \& Gleeson, M. (1997). Diet composition and the performance of high-intensity exercise. Journal of Sports Sciences, 15(3), 265-275. PubMed ID: 9232552 doi:10.1080/026404197367272
Maughan, R.J., \& Shirreffs, S.M. (2010). Development of hydration strategies to optimize performance for athletes in high-intensity sports and in sports with repeated intense efforts. Scandinavian Journal of Medicine \& Science in Sports, 20(Suppl. 2), 59-69. doi:10.1111/ j.1600-0838.2010.01191.x

McNaughton, L., \& Thompson, D. (2001). Acute versus chronic sodium bicarbonate ingestion and anaerobic work and power output. Journal of Sports Medicine \& Physical Fitness, 41(4), 456-462.

Painelli, V.S., Roschel, H., Gualano, B., Del-Favero, S., Benatti, F.B., Ugrinowitsch, C., ... Lancha, A.H., Jr. (2011). The effect of carbohydrate mouth rinse on maximal strength and strength endurance. European Journal of Applied Physiology, 111(9), 2381-2386. PubMed ID: 21336838 doi:10.1007/s00421-011-1865-8

Peeling, P., Castell, L.M., Derave, W., de Hon, O., \& Burke, L.M. (2019). Sports foods and dietary supplements for optimal function and performance enhancement in track-and-field athletes. International Journal of Sport Nutrition and Exercise Metabolism, 29. doi:10.1123/ ijsnem.2018-0271

Phillips, S.M., Tipton, K.D., Ferrando, A.A., \& Wolfe, R.R. (1999). Resistance training reduces the acute exercise-induced increase in muscle protein turnover. American Journal of Physiology, Endocrinology and Metabolism, 276(1 Pt 1), E118-E124. doi:10.1152/ ajpendo.1999.276.1.E118

Rankin, J.W., \& Gibson, J. (2015). Making weight. In L. Burke \& V. Deakin (Eds.), Clinical Sports Nutrition (5th ed., pp. 191-212). North Ryde, Australia: McGraw-Hill Education.

Rockwell, M.S., Rankin, J.W., \& Dixon, H. (2003). Effects of muscle glycogen on performance of repeated sprints and mechanisms of fatigue. International Journal of Sport Nutrition and Exercise Metabolism, 13(1), 1-14. PubMed ID: 12660402 doi:10.1123/ijsnem. 13.1.1

Ross, A., \& Leveritt, M. (2001). Long-term metabolic and skeletal muscle adaptations to short-sprint training: Implications for sprint training and tapering. Sports Medicine, 31(15), 1063-1082. PubMed ID: 11735686 doi:10.2165/00007256-200131150-00003

Ross, A., Leveritt, M., \& Riek, S. (2001). Neural influences on sprint running: Training adaptations and acute responses. Sports Medicine, 31(6), 409-425. PubMed ID: 11394561 doi:10.2165/00007256200131060-00002

Saraslanidis, P.J., Panoutsakopoulos, V., Tsalis, G.A., \& Kyprianou, E. (2011). The effect of different first 200-m pacing strategies on blood lactate and biomechanical parameters of the 400-m sprint. European Journal of Applied Physiology, 111(8), 1579-1590. PubMed ID: 21190037 doi:10.1007/s00421-010-1772-4

Saunders, B., Elliott-Sale, K., Artioli, G.G., Swinton, P.A., Dolan, E., Roschel, H., ... Gualano, B. (2017). beta-alanine supplementation to improve exercise capacity and performance: A systematic review and meta-analysis. British Journal of Sports Medicine, 51(8), 658-669. PubMed ID: 27797728 doi:10.1136/bjsports2016-096396

Savoie, F.A., Kenefick, R.W., Ely, B.R., Cheuvront, S.N., \& Goulet, E.D. (2015). Effect of Hypohydration on Muscle Endurance, Strength, Anaerobic Power and Capacity and Vertical Jumping Ability: A meta-analysis. Sports Medicine, 45(8), 1207-1227. PubMed ID: 26178327 doi:10.1007/s40279-015-0349-0

Skare, O.C., Skadberg, \& Wisnes, A.R. (2001). Creatine supplementation improves sprint performance in male sprinters. Scandinavian Journal of Medicine and Science in Sports, 11(2), 96-102. PubMed ID: 11252467 doi:10.1034/j.1600-0838.2001.011002096.x

Spencer, M.R., \& Gastin, P.B. (2001). Energy system contribution during 200 - to $1500-\mathrm{m}$ running in highly trained athletes. Medicine \& 
Science in Sports \& Exercise, 33(1), 157-162. PubMed ID: 11194103 doi:10.1097/00005768-200101000-00024

Stokes, T., Hector, A.J., Morton, R.W., McGlory, C., \& Phillips, S.M. (2018). Recent perspectives regarding the role of dietary protein for the promotion of muscle hypertrophy with resistance exercise training. Nutrients, 10(2), pii: E180.

Sugiura, K., Suzuki, I., \& Kobayashi, K. (1999). Nutritional intake of elite Japanese track-and-field athletes. International Journal of Sport Nutrition, 9(2), 202-212. PubMed ID: 10428572 doi:10.1123/ijsn. 9.2.202

Suzuki, Y., Ito, O., Mukai, N., Takahashi, H., \& Takamatsu, K. (2002). High level of skeletal muscle carnosine contributes to the latter half of exercise performance during 30-s maximal cycle ergometer sprinting. The Japanese Journal of Physiology, 52(2), 199-205. PubMed ID: 12139778 doi:10.2170/jjphysiol.52.199

Sygo, J., Coates, A.M., Sesbreno, E., Mountjoy, M.L., \& Burr, J.F. (2018). Prevalence of Indicators of Low Energy Availability in Elite Female Sprinters. International Journal of Sport Nutrition and Exercise Metabolism, 28(5), 490-496.

Thompson, C., Vanhatalo, A., Jell, H., Fulford, J., Carter, J., Nyman, L., . . . Jones, A.M. (2016). Dietary nitrate supplementation improves sprint and high-intensity intermittent running performance. Nitric Oxide, 61, 55-61. PubMed ID: 27777094 doi:10.1016/j.niox.2016.10.006

Tipton, K.D., Jeukendrup, A.E., Hespel, P., \& International Association of Athletics Federations. (2007). Nutrition for the sprinter. Journal of Sports Sciences, 25(Suppl. 1), S5-S15. doi:10.1080/ 02640410701607205

Tscholl, P., Alonso, J.M., Dolle, G., Junge, A., \& Dvorak, J. (2010). The use of drugs and nutritional supplements in top-level track and field athletes. American Journal of Sports Medicine, 38(1), 133-140. PubMed ID: 19812387 doi:10.1177/0363546509344071

Uth, N. (2005). Anthropometric comparison of world-class sprinters and normal populations. Journal of Sports Science and Medicine, 4(4), 608-616. PubMed ID: 24501574

van Loon, L.J., Saris, W.H., Kruijshoop, M., \& Wagenmakers, A.J. (2000). Maximizing postexercise muscle glycogen synthesis: Carbohydrate supplementation and the application of amino acid or protein hydrolysate mixtures. American Journal of Clinical Nutrition, 72(1), 106-111. PubMed ID: 10871568 doi:10.1093/ajcn/72.1.106

Viitasalo, J.T., Kyrolainen, H., Bosco, C., \& Alen, M. (1987). Effects of rapid weight reduction on force production and vertical jumping height. International Journal of Sports Medicine, 8(4), 281-285. PubMed ID: 3667026 doi:10.1055/s-2008-1025670

Vitale, K.C., Hueglin, S., \& Broad, E. (2017). Tart Cherry Juice in Athletes: A Literature Review and Commentary. Current Sports Medicine Reports, 16(4), 230-239. PubMed ID: 28696985 doi:10. 1249/JSR.0000000000000385

Watson, G., Judelson, D.A., Armstrong, L.E., Yeargin, S.W., Casa, D.J., \& Maresh, C.M. (2005). Influence of diuretic-induced dehydration on competitive sprint and power performance. Medicine \& Science in Sports \& Exercise, 37(7), 1168-1174. PubMed ID: 16015134 doi:10. 1249/01.mss.0000170100.93279.be

Watts, A.S., Coleman, I., \& Nevill, A. (2012). The changing shape characteristics associated with success in world-class sprinters. Journal of Sports Sciences, 30(11), 1085-1095. PubMed ID: 21916672 doi:10.1080/02640414.2011.588957

Weyand, P.G., Sandell, R.F., Prime, D.N., \& Bundle, M.W. (2010). The biological limits to running speed are imposed from the ground up. Journal of Applied Physiology, 108(4), 950-961. PubMed ID: 20093666 doi:10.1152/japplphysiol.00947.2009

Witard, O.C., Garthe, I., \& Phillips, S.M. (2019). Dietary protein for training adaptation and body composition manipulation in track-andfield athletes. International Journal of Sport Nutrition and Exercise Metabolism, 29. doi:10.1123/ijsnem.2018-0267

Witard, O.C., Jackman, S.R., Breen, L., Smith, K., Selby, A., \& Tipton, K.D. (2014). Myofibrillar muscle protein synthesis rates subsequent to a meal in response to increasing doses of whey protein at rest and after resistance exercise. American Journal of Clinical Nutrition, 99(1), 86-95. PubMed ID: 24257722 doi:10.3945/ajen .112 .055517

Wroble, K.A., Trott, M.N., Schweitzer, G.G., Rahman, R.S., Kelly, P.V., \& Weiss, E.P. (2019). Low-carbohydrate, ketogenic diet impairs anaerobic exercise performance in exercise-trained women and men: A randomized-sequence crossover trial. Journal of Sports Medicine \& Physical Fitness,59, 600-607. doi:10.23736/S00224707.18.08318-4

Zabala, M., Peinado, A.B., Calderon, F.J., Sampedro, J., Castillo, M.J., \& Benito, P.J. (2011). Bicarbonate ingestion has no ergogenic effect on consecutive all out sprint tests in BMX elite cyclists. European Journal of Applied Physiology, 111(12), 3127-3134. PubMed ID: 21465247 doi:10.1007/s00421-011-1938-8 